Зборник радова Учитељског факултета, 9, 2015, стр. 203-215

COBISS.SR-ID 218380044

\author{
Проф. др Синиша Г. Минић ${ }^{47}$
}

Учитељски Факултет у Призрену - Лепосавић

\title{
Мирјана Воркапић
}

ОШ „Васа Пелагић“ у Београду

\section{ИНФОРМАТИКА У ПРОГРАМИРАНОЈ НАСТАВИ МАТЕМАТИКЕ ЗА УЧЕНИКЕ МЛАЪИХ РАЗРЕДА ОСНОВНЕ ШКОЛЕ}

\begin{abstract}
Апстракт: Уовом раду покушали смо да прикажемо колики је допринос програмиране наставе за ученике млађих разреда основних школе, односно да на конкретним примерима прикажемо значај и улогу при имплементачији у традиционалну наставу. Постоји велики дисбаланс на релацији учитељ-ученик, како по прихватању тематских јединица, тако и по начину обраде истих. Управо, са ове тачке гледишта потребно је да се укаже колики је допринос оваквог начина рада када су у питању деца различитих психо-физичких и моторних способности.
\end{abstract}

Кључне речи: математика, програмирање, линеарно програмирање, разгранато програмирање, информатика.

\section{УВОД}

Мора да се има у виду да су наставници оптерећени администрацијом која на својеврстан начин „убија“ креативност и неку могућност увођења новина у наставу. Међутим, није администрација једини „кривац“. Конзервативизам великог дела наставника потиче од несигурности у нове методе, технике и средства. Пратећи нову технологију, наставник и ученици подижу наставу на виши мисаони ниво, баве се анализом, синтезом, закључивањем.

Успех програмиране наставе информатике у савладавању градива математике у великој мери зависи од програма у којем се припрема (Word, Excell, Word Pad). Програм који се користи за програмирану наставу, мора да испуни одређене захтеве (разумљивост, одређеност и резултативност). Најважнији чинилац који утиче на избор модела програма је узраст ученика. Постоје два основна модела програмирања: линеарни и разгранати, а трећи модел је комбинација претходна два.

Тема овог рада је примена информатике у програмираној настави и њени ефекти у настави математике, и то првенствено у млађим разредима

${ }^{47} \underline{\text { sinisa.minic@pr.ac.rs }}$ 
основне школе (од првог до четвртог разреда). Након теоријске анализе, биће наведени резултати истраживања како би се показали ефекти програмиране наставе. На крају рада, биће приказан и пример програмираног материјала који се може применити на часовима математике у разредној настави.

\section{ПОЈАМ ПРОГРАМИРАНЕ НАСТАВЕ}

Програмирана настава се дефинише на следећи начин: „Програмирана настава је такав вид наставе у којој се наставно градиво на посебан начин логички структурира и даје ученицима у мањим, раније припремљеним, деловима, које они усвајају самостално, поступно, идући корак по корак сопственим ритмом и проверавајући степен усвојености тих садржаја помоћу сталне и текуће повратне информације“ (Продановић и Ничковић, 1974:372). Стевановић и Ђорђевић (1981: 79) наводе основне одлике програмиране наставе:

1. Ученик усваја програм поступним самосталним изучавањем тзв. „чланака“, „секвенци“ и тема у којима су наставни садржаји тачно одређени (програмирани) и логички структурирани (алгоритмовани).

2. Ученици напредују у процесу усвајања садржаја корак по корак сопственим ритмом и самостално, без непосредног учешћа наставника.

3. Усвајање наставних садржаја, изложених у „порцијама““ (дозама), систематски се проверава помоћу текућих повратних информација, при чему сваки ученик прелази на наредни „корак“ само уколико је усвојио претходне етапе (поступност и мотивација).

Програмирана настава се још назива и „програмер” и ,алгоритам”. Алгоритам у програмираној настави значи прецизно упутство за извршење низа операција, односно логичко низање садржаја. Алгоритам је битно својство програмиране наставе. Реч „програмер“ означава стручно лице (наставника или друго посебно обучено лице) које саставља програме, односно програмиране материјале. Познавање принципа програмирања постаје данас саставни део наставниковог педагошко-дидактичког образовања.

Веома битан сегмент ове наставе је стално поткрепљење код тачних одговора и решења (Богићевић, 1974: 307). Програмирана настава је вид наставе у којој је наставни садржај логички структуиран и дат ученицима у мањим „порцијама“, које они самостално усвајају, постепено савлађујући корак по корак сопственим ритмом, и проверавајући степен усвојености тих садржаја помоћу сталне повратне информације. Путем програмиране наставе обезбеђује се индивидуализација учења, учење је систематично, поступно, ученик се директно и непосредно обавештава о резултатима свога напредовања.

Код израде програмираног материјала потребно је имати у виду следеће фазе (Мужић, 1974: 21-24): 1. Избор градива које ће се програмирати, 2. Оперативно одређење задатака програма, 3. Састављање инструмената за 
контролу успеха, 4. Одређивање потребних предзнања и особина ученика, 5. Детаљна анализа градива, 6. Онганизација и систематизација градива,

7. Писање самог програма, тј. писање чланака и њихово ређање у секвенце, 8. Рецензија, 9. Израда упитника за примену и припрема за примену (штампање, умножавање, емитовање и сл.).

\section{ОСНОВНИ ПОЈМОВИ У ПРОГРАМИРАНОЈ НАСТАВИ}

У програмираној настави срећу се појмови: програм, тема, секвенца, чланак (корак, порција, доза), алгоритам.

$\checkmark$ Програм прецизно излаже битне чињенице и појмове које ученици треба да савладају. Данас се програм најлакше представља помоћу рачунара. Грађа је разложена на логично повезане и за усвајање, лаке мале делове који се савлађују један за другим. Делови су поређани по сложености и савладаност претходног нивоа је услов за прелазак на следећи ниво. Зато се садржаји не могу прескакати. Програм може бити потпун и делимичан. Програм се састоји од тема, теме од секвенци, а секвенце од чланака.

$\checkmark \boldsymbol{T e m a}$ се састоји од групе секвенци које се односе на део наставног програма и чине већу садржајну и логичку целину.

$\checkmark$ Секвенца је логички структуиран део теме. Састоји се из више чланака, а обрађује део тематске целине ( нпр. обим троугла).

$\checkmark$ Чланак је таква јединица знања са којом се ученик среће када решава неки проблем, задатак или одговара на неко питање. Усвојена информација је услов да се пређе на следећи, садржајно сложенији, чланак. Чланак садржи следеће елементе: уводна информација којом се ученик обавештава о новом градиву; задатак (проблем) који треба решити; простор за решавање задатака; повратна информација коју ученик треба да погледа тек када сам до краја уради задатак и провери да ли је његово решење тачно (Мужић, 1981:45).

$\checkmark$ Алгоритам у програмираној настави значи прецизно упутство за извршење низа операција (које воде решавању неког проблема) и логичко низање садржаја. Захтеве које треба да испуни алгоритам су: 1.) одређеност, 2.) масовност; 3) резултативност (Вилотијевић, 2000:270).

$\checkmark$ Програмер је стручно лице (наставник или друго оспособљено лице) које саставља програме, одн. програмиране материјале. Познавање принципа програмирања постаје саставни део наставниковог педагошко-дидактичког образовања.

\section{ЗАДАТАК И ЊЕГОВО РЕШАВАЊЕ}

Задатак и његово решавање служе да изазову оне активности код ученика које су битне за адекватно усвајање градива, односно за пријем и 
прераду информација. Мужић (1981:63-65) наводи два типа задатака који се најчешће примењују у програмираним материјалима: задаци конструкције и задаци препознавања. Задаци конструкције су они које ученик самостално формулише, и који захтевају извесну стваралачку активност. Према истом извору, код задатака конструкције најчешће су у употреби два типа задатака : директни задаци и задаци допуњавања.

\section{ЛИНЕАРНИ ПРОГРАМИ ЗА ПРОГРАМИРАНУ НАСТАВУ}

Линеарни програм је креирао Скинер (Скинер, 1954) полазећи од својих принципа програмиране наставе „корак по корак“. Чланци су у том програму поређани праволинијски (видети слику 1). У линеарном програмирању сви ученици решавају исте задатке постављеним редом и својим ритмом, у зависности од предзнања и сазнајних могућности (Баковљев, 1979:30). Ученик не бира одговоре, јер му то није ни понуђено, и то га мисаоно активира. Али, може да провери тачност решења јер му је у програму дато решење. Тачан одговор води ка позитивном поткрепљењунагради, а негативан је везан за потребу да се понови рад на датом задатку.

Линеарни програм састоји се од мноштва уситњених чланака, који садрже информацију, задатак и решење задатка. Решење се најчешће налази на маргини следећег чланка, а може бити и на крају програмираног материјала. Да не би погледали решење пре него што сами дају одговор, решење задатка се прекрива траком. Тек када ученик самостално формулише одговор, открива се решење задатка.

Међутим, задаци и њихова решења су често на различитим страницама. Први чланак се налази на почетку прве странице, други на почетку друге странице, трећи на почетку треће странице. Ситуација са решењима је следећа: решење првог чланка се налази на почетку друге, решења другог на почетку треће странице, решења трећег чланка на почетку четврте странице... За линеарни програм наводе се следеће карактеристике:

Ученик је самосталан у формулацији, конструкцији одговора, и за свој одговор убрзо добија информацију о тачности решења и тим је подстакнут да у раду иде даље;

Сви ученици раде и савладавају градиво истовремено, по истом програму;

Чланци су кратки;

Чланци су распоређени у линеарном низу, напредовање зависи од психофизичких способности, тако да бољи ученици прескачу једноставнија питања. 


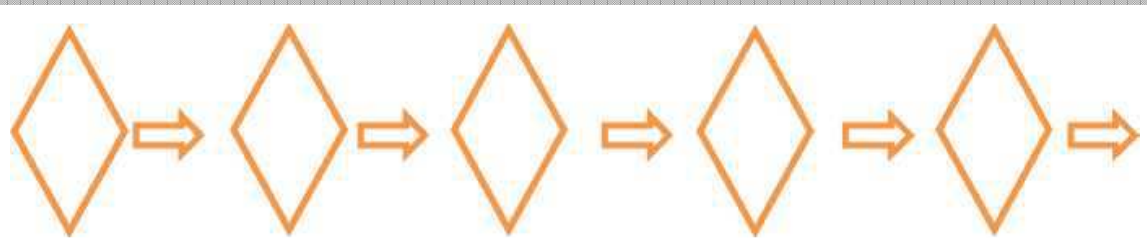

Слика 1: Шематски приказ линеарног програмирања (Вилотијевић, 2000)

Добра страна линеарних програма је што омогућава сваком ученику да напредује индивидуалним темпом, а слабост што не дају могућност за тражење додатних информација, које нису укључене у задатак. Те информације су неким ученицима неопходне да би дошли до решења. Линеарни програм индивидуализује само ритам савлађивања, али не и разлике у способностима ученика, које неоспорно постоје.

\section{ПРИМЕР ЛИНЕАРНОГ ПРОГРАМИРАЊА}

Илустрације ради навешћемо пример линеарно програмираног материјала намењен ученицима четвртог разреда основне школе који се ради y Word-u.

\section{УПУТСТВО ЗА РАД}

Писани материјал решава се самостално. Садржаји су подељени на деловечланке који су нумерисани следећим редом којим се наставна јединица поступно савлађује. Сваки чланак се састоји из обавештења, задатка, простора за решавање и тачног решења постављеног задатка.

Рад почиње пажљивим читањем обавештења. После тога одговорити на постављено питање или решити задатак. Након одговора или решења проверити његову тачност. Тачан одговор и решење налазе се лево од обавештења следећег чланка, а означени су редним бројем чланка уз који је задатак постављен. Тако, одговор на питање у првом чланку, налази се са леве стране обавештења другог чланка, итд.

Када се правилно одговори на питање или реши задатак, прелази се на следећи чланак. Уколико одговор није тачан, поново мора да се чита чланак и поново решава задатак.

Ако нешто није јасно, обратити се наставнику. СРЕЋНО!

\section{1. ЧЛАНАК}

При множењу два броја често се сусрећемо са случајевима када су оба чиниоца једнака, на пример:

Одговори на питања из претходног чланка
$2 * 2=4$

$3 * 3=9$

\section{$4 * 4=16$}

У овим случајевима кажемо да се број множи сам са собом.

1) Колико се добија када се број 6 помножи сам са собом. 


\begin{tabular}{|c|c|}
\hline 1) 36 & $\begin{array}{l}\text { 2. ЧЛАНАК } \\
\text { Производ } 2 * 2 \text { записујемо } \mathbf{2}^{2} \text {, читамо „2 на квадрат или } 2 \text { на } \\
\text { други степен“. } \\
\text { Производ } \mathbf{3 * 3} \text { записујемо } \mathbf{3}^{2} \text {, читамо , } 3 \text { на квадрат или } 3 \text { на } \\
\text { други степен“ } \\
\text { 1) Запиши } 4 * 4 \text { на упознати начин } \\
\text { 2) Прочитај запис } \mathbf{5}^{2}\end{array}$ \\
\hline $\begin{array}{l}\text { 1) } \mathbf{4}^{\mathbf{2}} \\
\text { 2) ,,5 на } \\
\text { квадрат или } \mathbf{5} \\
\text { на други } \\
\text { степен““ }\end{array}$ & 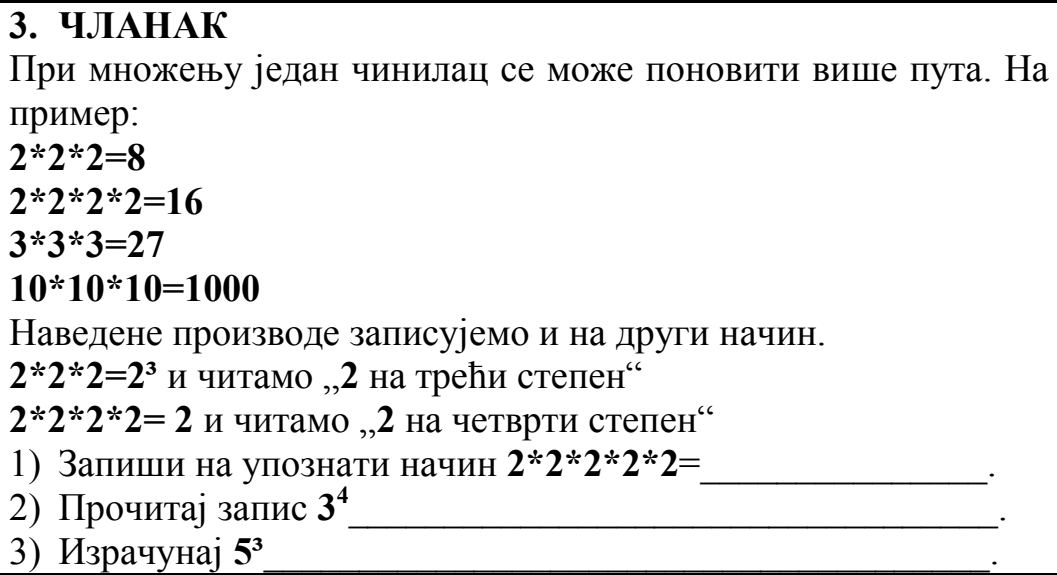 \\
\hline $\begin{array}{l}\text { 1) „2 на пети } \\
\text { степен“ } \\
\text { 2) „3 на } \\
\text { четврти } \\
\text { степен“ } \\
\text { 3) } 5 * 5 * 5=125\end{array}$ & $\begin{array}{l}\text { 4. ЧЛАНАК } \\
\text { Операцију множења једнаких чинилаца називамо степеновање. } \\
\text { Шта је степеновање? }\end{array}$ \\
\hline
\end{tabular}

\begin{tabular}{|l|l|}
\hline & 5. ЧЛАНАК \\
Степеновање је & Производ једнаких чинилаца називамо степен. Број који се \\
операција & понавља као чинилац јесте основа степена, а број који показује \\
множења истих & колико пута се чинилац понавља изложилац степена. \\
чинилаца. & 1) Шта је основа степена $\mathbf{4}^{\mathbf{3}}$ ? \\
& 2) Шта је изложилац степена $\mathbf{3}^{4}$ \\
\hline
\end{tabular}

1) Основа је 4

6. ЧЛАНАК

2) Изложилац Производ $\mathbf{a} * \mathbf{a}$ записујемо $\mathbf{a}^{2}$, а производ $\mathbf{a} * \mathbf{a} * \mathbf{a}$ записујемо $\mathbf{a}^{3}$. je 4

1) Запиши у облику производа $\mathbf{a}^{3}$

3) Основа је 3, а изложилац 5

2) Запиши производ $\mathbf{a} \mathbf{a}^{*} \mathbf{a} * \mathbf{a}$ у облику степена

\section{$7 . \quad$ ЧЛАНАК}

У линеарном програму ученик долази сам до решења. Ако тада погреши, он то констатује упоређивањем решења са повратном информацијом, па поново проучава дату информацију и прелази на наредни чланак, баш као и ученик који није грешио. 


\section{РАЗГРАНАТИ ПРОГРАМИ ЗА ПРОГРАМИРАНУ НАСТАВУ}

Разгранати програм, отклања слабости праволинијског програма, и омогућава способнијим ученицима да брже напредују, у складу са њиховим способностима (Кадум и Љубковић, 2001). Разгранати систем програмирања настоји да узме у обзир и индивидуалне разлике према способностима чиме се индивидуализују поступци учења. Код оваквог програмирања постоји могућност „прескакања“ једног или више чланака, уколико ученик та знања поседује, а ако не зна, ученик се упућује на допунску информацију или се поново враћа на онај чланак од ког зависи даље напредовање (Живковић и др., 2010:140).

У њему су чланци поређани и линеарно, али иду и скоковито и бочно, с тим што се ти бочни чланци наслањају на најближи праволинијски. Уз сваки задатак дато је више одговора, при чему ученик бира онај који сматра тачним. Иза сваког понуђеног одговора означи се, обично у загради, страница на коју треба да пређе онај који га је одабрао. На тој страници сазнаје се да ли је избор исправан, па се у зависности од тога, добијају нова решења или нови задатак или допунска објашњења онима који су погрешили.

Код разгранатих програма на једној страници је само један чланак. Ако се ученицима нуде за избор три одговора, најмање две од сваке три странице не садрже комплетан, већ окрњени чланак. На две трећине страница се не излажу нова знања, задаци и решења, већ се онима који греше при бирању одговора казује да су погрешили, пружају им се додатна објашњења и даје упутство да се коригују (Баковљев, 1972:80-81).

Те странице су намењене искључиво ученицима којима је неопходна помоћ за усвајање одређеног знања. Странице на којима се срећу чланци без информације служе за утврђивање и увежбавање знања. Све стране, тј. обе врсте садрже инструкције. То су оне назнаке страница (у заградама) уз сваки понуђени одговор, које казују на којој страници треба да настави рад онај ко је одређени одговор изабрао.

Разгранати програм се састоји од: а) информације, б) питања или задатка, в) избора тачног одговора. Графички прикази разгранатог програма дат је на слици 2.

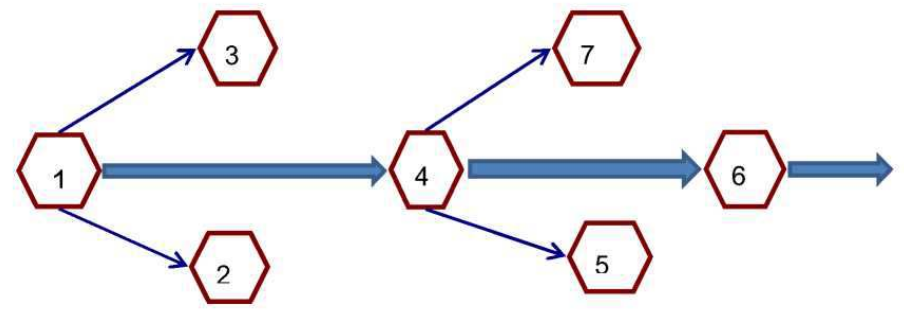

Слика 2: Шематски приказ разгранатог програма (Вилотијевић, 2000) 
Разгранати програм омогућује индивидуализацију, тако што ученик може да „прескочи“ чланке које зна. Они ученици који имају више знања крећу се праволинијски, док они чије су знање и способности мање иду изломљеном, „цик-цак“ линијом. Поред индивидуализације која је овде присутна, битна одлика разгранатог програма је и диференцијација наставних садржаја и поступака. Недостатак му је мања мисаона активност ученика који не решавају задатак већ бирају понуђено решење.

\section{ПРИМЕР РАЗГРАНАТОГ ПРОГРАМИРАЫА}

Илустрације ради, навешћемо пример разгранато програмираног материјала намењен ученицима четвртог разреда основне школе, који се ради у Word-u.

\section{УПУТСТВО ЗА РАД}

Добијени писани материјал проучава се самостално. Садржаји су подељени на чланке. Прелазак на следећи чланак одређен је тачношћу изабраног одговора на постављено питање у чланку који се чита. Сваки чланак се састоји из обавештења, задатка, понуђених одговора и упутства на којој страници треба да се провери исправност одговора.

Рад почиње пажљивим читањем обавештења. Пре одабира понуђених делова одговора треба добро размислити. После избора одговора, прочитају се упутства на којој страници се може проверити тачност одговора.

Када се правилно одговори на питање или реши задатак, прелази се на следећи чланак, и поново бирају одговори.

Уколико нешто није јасно, питати учитеља. СРЕЋНО!

\section{1. СТPAHA}

При множењу два броја често сусрећемо случајеве када су чиниоци једнаки, нпр.:

$$
\begin{aligned}
& 2 * 2=4 \\
& 3 * 3=9
\end{aligned}
$$

У овом случају кажемо да се бројеви множе сами собом.

Колико се добија када се број 4 користи два пута као чинилац?

Одговори:

6
8
16

6

16
Погледај страницу

2
3
4

3

4

\section{CTPAHA}

\section{Погрешио си!}

Уместо да множиш 4 са 4 , ти си сабрао 4 и 2. Врати се на 1 . страну, поново је прочитај и одабери одговор.

\section{CTPAHA}

\section{Погрешио си!}

Уместо да множиш 4 са 4 , ти си множио 4 и 2. Врати се на 1. страну, поново је прочитај и одабери одговор. 


\section{CTPAHA}

Одговор је тачан.

Производ $\mathbf{2}$ 2 2 записујемо и овако $\mathbf{2}^{\mathbf{2}}$ и читамо „2 на квадрат или $\mathbf{2}$ на други степен“. Производ 3 *3 записујемо и овако $3^{2}$ и читамо „3 на квадрат или 3 на други степен“. Како записујемо 4 *4?
Одговори:
Погледај страницу
2
5
$4^{2}$
6
$2 * 4$
7

\section{CTPAHA}

\section{Погрешио си!}

Ниси уочио разлику између броја који се множи и броја колико пута се чинилац понавља.Врати се на 4. страну.

\section{5. СТPAHA}

Одговор је тачан.

При множењу један чинилац може да се понови више пута, нпр.:

$2 * 2 * 2=8$

$2 * 2 * 2 * 2=16$

$3 * 3 * 3=27$

\section{$10 * 10 * 10=1000$}

Наведене производе записујемо на други начин:

$2 * 2 * 2=23$ и читамо , 2 на трећи степен“

$2 * 2 * 2 * 2=2$ и читамо ,2 на четврти степен“

Производ $3 * 3 * 3 * 3$ записујемо на други начин?

Одговори:

\begin{tabular}{cc}
3 & 8 \\
4 & 9 \\
$3 * 4$ & 10 \\
\hline
\end{tabular}

\section{CTPAHA}

\section{Погрешио си!}

Ниси схватио разлику између множења броја 4 и 2 и множења 4 са самим собом. Врати се на 4. страну.

\section{7. СТРАНА}

Одговор је тачан.

Операцију множења једнаких чинилаца називамо СТЕПЕНОВАЮЕ, а производ једнаких чинилаца је СТЕПЕН. Број који се понавља као чинилац је ОСНОВА СТЕПЕНА.

Шта је основа степена 3 ?

Одговори:

4

3

\section{Погледај страницу}

11

12

\section{CTPAHA}

\section{Погрешио си!}

Ниси схватио шта значи када се чинилац понавља више пута као чинилац. Врати се на 6 . страну. 


\section{9. СТРАНА}

\section{Погрешио си!}

Мешаш множење 3 са 4 и случај када се 3 јавља 4 пута као чинилац. Врат се поново на 6. страну.

\section{CTPAHA}

\section{Погрешио си!}

Не правиш разлику између чиниоца који се понавља и броја његовог понављања. Врати се на 8. страну.

\section{CTPAHA}

\section{Одговор је тачан.}

Број који показује колико се пута чинилац понавља називамо изложилац степена. Шта је изложилац степен?

\section{МОТИВИСАЊЕ УЧЕНИКА ЗА ПРОГРАМИРАНУ НАСТАВУ}

Скинер (1954) критикује традиционалну наставу и истиче предности програмиране наставе имајући у виду начин решавања проблема мотивисања ученика. Према њему, у традиционалној настави, испитивањем се утврђује шта ученик зна, а не шта не зна.

Фурлан (1991) тврди да је програмирано учење добро мотивисано својом унутрашњом структуром и организацијом, а не жељом за похвалом, добром оценом, страхом од казне, слабом оценом. Сматра да поменути мотиви заједнички делују и да њих не треба искључивати.

Између креативности и постигнућа постоји скромна негативна корелација. Програмирани методи ограничавају оригиналност мишљења. Последњи закључак је да није нађена значајна корелација између потребе за постигнућем и ефикасности програмиране инструкције.

Посебну пажњу привлачи однос креативности и постигнућа. Ако програмирана настава не погодује развоју стваралаштва, већ је у раскораку са њим, много би изгубила од својих вредности.Као пример можемо навести, да је важно какв је однос између постигнућа и креативности код различитих варијанти линеарног програма а нарочито између линеарног и разгранатог програма.

Повратна спрега је механизам којим се остварује мотивисање у програмираној настави. После сваке секвенце ученик добија потврду уколико је добро урадио задатак, или ако није, онда информацију, како треба да одговори. Повратном спрегом остварује се интеракција на релацији: ученик-градиво. Овај контакт са градивом мотивише ученика за оптималнији доживљај градива. Једини контакт који има са градивом јесте усвајање градива. Повратна спрега омогућује ефикасно усмеравање процеса учења. Предност је у могућностима вођења ученика, што обавезује ауторе програма. Због тога је израда програма изузетно одговоран посао. Повратна спрега 
служи ученику, наставнику а може да послужи и истраживачу који се бави програмираном наставом.

Програмирана настава математике истиче следеће вредности (Радојевић и Радојевић, 1987:57);

- активност ученика у процесу стицања знања,

- брзину усвајања градива ученик прилагођава својим способностима,

- прелазак на нови радни задатак условљен је успешним решењем свих претходних,

- сазнања се практично примењују,

- учени се стално обавештава о резултатима свога рада.

Нажалост, програмирана настава има и неких недостатака, а као највећи недостатак сматра се слаба социјализација. Применом програмиране наставе битно је умањена могућност кооперације и међусобне помоћи међу ученицима. Међутим, сматра се да се овај недостатак може надокнадити комбинацијом са другим облицима наставе. Уосталом, свакако да није добро базирати се само на једној настави, јер свака настава поред својих предности има и недостатке. Најбоље је, или комбиновати на једном часу више облика наставе, или мењати наизменично разне врсте наставе, што доводи до веће активности и мотивације ученика за рад.

\section{ЗАКЉУЧАК}

Често се истичу недостаци класичне (традиционалне) наставе. Како би формирали ученике који су функционално способни, истиче се потреба унапређивања васпитно-образовног процеса. Да би се остварили циљеви унапређивања наставе, једна од могућности је употреба програмиране наставе.

Под појмом програмирани материјал убрајамо: програмирани уџбеници, програмиране наставне теме или наставне јединице. Информација је елементарни садржај који ученик треба да усвоји. Питање величине информације, које се у поједином чланку пружа ученику, у вези је с величином корака. Кораком се сматра сазнајна дистанца између два чланка. Дужина корака треба да буде пропорционална узрасту ученика, што млађи узраст, то мањи кораци. Такође, мора да се води рачуна о томе да кораци буду мањи, уколико се ученици срећу први пут са програмираним материјалом, и да се при ширењу опсега корака не заборави и потреба њихове примерености и за најслабије ученике.

Видели смо на конкретним примерима колико је битно увести линеарно и разгранато програмирање, нарочито за млађе разреде основне школе. Код линеарног програма, чланци су тако састављени и поређани да ученик иде праволинијски, корак по корак, својим темпом; ученик не бира одговоре, јер му то није ни понуђено, и то га мисаоно активира. 
Разгранати програм, отклања слабости праволинијског програма, и омогућава способнијим ученицима да брже напредују, у складу са њиховим способностима. Разгранати програм омогућује индивидуализацију, тако што ученик може да „прескочи“ чланке које зна.

Највећа предност програмираног учења је што се овом методом учи како треба учити, мислити, закључивати и повезивати претходно научено градиво са следећим. Самостално извођење експеримената програмираном наставом, ученик се као појединац и као део одељења/групе, уводи у мали истраживачки рад, оспособљава се за самообразовање.

Програмирано учење има предности и за наставника. Многи сматрају да се улога наставника смањује. Напротив, одговорност му се повећава. Уместо да предаје, излаже градиво, увежбава, испитује, он анализира ток програмираног учења, вредност програма, постигнуте резултате, то му омогућава да увиди шта је добро, а шта лоше у програму наставе математике, уопште, другим предметима, која група ученика боље напредује. Наставник је у могућности да интервенише у самом процесу учења. Самим тим дубље упознаје процес учења. Предлог овог рада је да се програмирано учење што чешће примењује у настави математике, али не као једини облик рада, већ у комбинацији са другим облицима рада.

\section{Лuтература}

Продановић, Т. и Ничковић, Р. (1974): Дидактика. Београд: Завод за уџбенике и наставна средства

Стевановић, М. и Ђорђевић, Д. (1981): Организација наставе у комбинованим одељењима. Горњи Милановац: Дечје новине.

Богићевић, М. (1974): Технологија савремене наставе. Београд: Завод за уџбенике и наставна средства.

Мужић, В. (1974): Програмирана настава. Загреб: Школска књига.

Мужић, В. (1981): Програмирана настава. Загреб: Школска књига.

Вилотијевић, М. (2000): Дидактика 1, 2 и 3. Учитељски факултет. Београд: Научна књига.

Skinner, B. F. (1954): The science of learning and the art of teaching. Cambridge, Mass, USA, 99-113.

Баковљев М. (1979): Програмирана настава интерпункције. Београд: Институт за педагошка истраживања.

Кадум, В. и Љубковић, J. (2001): Програмирани уџбеници за математику. Њихова структура и досадашња искуства у њиховом састављању и примени. Други стручно-методички скуп. Методика наставе математике у основној и средњој школи. 
Живковић, Л., Јовановић, С. и Асентић, Ж. (2010): Theoretical frame of the programmed teaching method of geography. Зборник радова-Географски факултет Универзитета у Београду, (58), 137-152.

Баковљев, М. (1972): Теоријске основе програмиране наставе. Београд: НИП Дуга.

Фурлан, И. (1991): Психологија подучавања, Загреб: Школска књига.

Радојевић, П. и Радојевић, В. (1987): Методика наставе математике. Београд: Завод за уџбенике и наставна средства.

\section{INFORMATICS IN PROGRAMMED TEACHING OF MATHEMATICS FOR PUPILS OF LOWER CLASSES OF PRIMARY SCHOOL}

Summary: This paper deals with our effort to present contribution of programmed teaching for the pupils of primary school lower classes, that is to illustrate with concrete examples of the importance and the role of its implementing into traditional way of teaching. There is a great disbalance in relation of pupil-teacher, both in accepting thematic units and their presentation. Exactly from this point of view, it is necessary to stress the contribution of this form of work especially in regard to children of different psycho-physical and motoric abilities.

Key words: mathematics, programming, linear programming, branch programming, informatics. 